\title{
ZuZAZnNA BENINCASA
}

Uniwersytet Warszawski

\section{PRAWO ZASTAWU JAKO ZABEZPIECZENIE ROSZCZENIA O ZWROT POŻYCZKI MORSKIEJ W D. 22,2,6}

Charakterystyczna cechą kontraktu pożyczki morskiej ${ }^{1}$ było prze-

${ }^{1} \mathrm{Na}$ temat kontraktu pożyczki morskiej w prawie greckim por. przede wszystkim U.E. Paoli, Studi di diritto attico, Firenze 1930, s. 9-137; J. VÉlissaropoulos, Les nauclères grecs. Recherches sur les institutions maritimes en Grèce et dans l'Orient hellénisé, Geneve-Paris 1980, s. 301-311; G. PurPura, Tabulae Pompeianae 13 e 34: due documenti relativi al prestito marittimo, [w:] Atti del XVII Congresso Internazionale di Papirologia, Napoli 1984, 1245-1266 = Tabulae Pompeianae 13 e 34: due documenti relativi al prestito marittimo, [w:] Studi romanistici in tema di diritto commerciale marittimo, Rubbettino 1996, s. 243 n. 1; A. Castresana Herrero, El prestamo maritimo griego y la pecunia traiecticia romana, Salamanca 1982 s. 20-50; E.E. Cohen, Athenian Finance: maritime and landed Yields, «Classical Antiquity» 8/1989, s. 207-223; S. Schuster, Das Seedarlehen in den Gerichtsreden des Demosthenes mit einem Ausblick auf die weitere historische Entwicklung des Rechtsinstitutes: dáneion nautikón, fenus nauticum und Bodmerei, Berlin 2005 oraz recenzja z tej pracy G. Thüra, «ZSS»124/2007, s. 682-684; E. M HARrIs, Law and Economy in classical Athens: [Demostenes] against Dionysosdorus, [w:] Democracy and the rule of law in classical Athens: essays on Law, Society and Politics, Cambridge 2006, s. 143-162. Wykaz literatury dotyczącej rzymskiego kontraktu pożyczki morskiej w: E. Castresana Herrero, op. cit.; G. Purpura, Ricerche in tema di prestito marittimo, «AUPA» 39/1987, s. 189-335 = Ricerche in tema di prestito marittimo, [w:] Studi romanistici in tema di diritto commerciale marittimo, Rubbettino 1996, s. 95-239. Najnowsze publikacje poświęcone temu kontraktowi to przede wszystkim: H Ankum, Some Aspects of Maritime Loans in Old-Greek and in Roman Law, [w:] Timai, Athen 2000, s. 293-306; J.G. Wolf, Aus den neuen pompejanischen 
jęcie przez pożyczkodawcę, finansującego przedsięwzięcie związane $\mathrm{z}$ handlem morskim, ryzyka utraty pożyczonych środków w sytuacji, w której statek, na którym pożyczkobiorca transportował nabyte z pożyczonych środków towary, nie dopłynął do portu przeznaczenia. Pożyczkodawca miał prawo żądania zwrotu pożyczonych pieniędzy tylko jeżeli spełnił się warunek 'si salva navis pervenerit', co oznaczało, iż brał na siebie ryzyko zatonięcia statku z przyczyn związanych z nawigacją. W zamian za to ryzyko, miał prawo, w przypadku szczęśliwego zakończenia podróży, do żądania od pożyczkobiorcy, obok zwrotu kwoty pożyczki, również odsetek, przewyższających znacznie maksymalne limity ustawowo przewidziane dla kontraktu mutuum ${ }^{2}$. Odsetki te, odmiennie, niż miało to miejsce w zwykłym kontrakcie pożyczki, nie stanowiły wynagrodzenia za umożliwienie korzystania z kapitału, ale rekompensatę za ponoszone przez pożyczkodawcę ryzyko i jednocześnie formę uczestnictwa w zyskach ze wspólnego przedsięwzięcia. Ich wysokość nie była ograniczona przez ustawowe regulacje dotyczące kontraktu mutuum, a prawo do ich pobierania było ściśle skorelowane z periculum creditoris i ustalonym $\mathrm{w}$ umowie terminem, w którym wierzyciel brał na siebie ryzyko zatonięcia statku.

Urkundenfund: Die 'naulotike' des Menelaos - Seedarlehen oder Seefrachtvertrag, [w:] 'Iuris Vincula'. Studi in onore di Mario Talamanca, Napoli 2001, s. 421-463; H. AnKum, Noch einmal: Die naulootike des Menelaos in TP 13 (=TPSulp. 78 - ein Seedarlehen oder ein Seefrachtvertrag?, [w:] Roman Law as Formative of Modern Legal Systems. Studies in Honour of Wiestaw Litewski, Kraków 2003, s. 15-23; S. Schuster, op. cit.; E. Chevreau, 'La traiecticia pecunia': un mode de financement du commerce international, «MHSDB» 65/2008, s. 37-47; B. STELZENBERGER, Kapitalmanagement und Kapitaltransfer im Westen des Römischen Reiches, «Pharos» 23/2008, s. 108-123.

${ }^{2} \mathrm{~W}$ greckiej pożyczce morskiej odsetki te zwyczajowo wynosiły około $33 \%$ kwoty zainwestowanego przez pożyczkodawcę kapitału. Jak można przypuszczać, także w rzymskim kontrakcie pecunia traiecticia wysokość odsetek kształtowała się na porównywalnym poziomie, chociaż fragment PS mówi nawet o infinitas usuras. Por. PS. II,14,3: ... quamdiu navigat navis, infinitas usuras recipere potest. Na temat odsetek w rzymskiej pożyczce morskiej por. G. PURPURA, Ricerche..., s. 220-227; B. STELzenBerger, op. cit., s. 115. 
Aby ograniczyć i kontrolować przyjęte na siebie ryzyko, pożyczkodawca zastrzegał sobie w kontrakcie szereg klauzul, mających na celu zminimalizowanie ryzyka nastapienia zdarzeń, które mogłyby spowodować nieziszczenie się warunku si salva navis pervenerit ${ }^{3}$. Do takich klauzul można zaliczyć przede wszystkim umowne określanie trasy podróży i dat, w których powinny być podjęte poszczególne etapy rejsu, celem wyeliminowania tras i portów potencjalnie niebezpiecznych oraz ominięcia pór roku, w których żegluga stawała się zbyt niebezpieczna. Innym sposobem, który miał pożyczkodawca na zmniejszenie ponoszonego ryzyka, było określenie terminu (dies praestitutus), przekroczenie którego powodowało, niezależnie od tego czy statek wypłynął z portu, czy do niego przypłynął, zwolnienie go z ryzyka wiążącego się z żeglugą. Tym samym pożyczkodawca zabezpieczał się przed przekroczeniem przez pożyczkobiorcę umówionych terminów podróży przewidzianych w kontrakcie i w konsekwencji przedłużeniem podróży na okres, w którym zwiększało się ryzyko związane z nawigacją. Kolejnym sposobem kontroli ponoszonego ryzyka było wysyłanie w podróż z pożyczkobiorcą niewolnika-agenta, którego zadaniem było nadzorowanie przebiegu realizacji kontraktu, pod kątem ustaleń poczynionych w umowie i ewentualnie podejmowanie decyzji o natychmiastowej spłacie pożyczki. Wspomniane wyżej instrumenty służyły zwiększeniu prawdopodobieństwa ziszczenia się warunku si salva navis pervenerit, a więc zapewnieniu pożyczkodawcy możliwości skutecznej realizacji jego roszczenia o zwrot zainwestowanej kwoty pożyczki wraz z odsetkami. Dzięki ich zastosowaniu, wierzyciel mógł, w takim zakresie, w jakim było to możliwe, zaplanować i kontrolować ryzyko, jakie brał na siebie inwestując pieniądze w przedsięwzięcie związane z handlem morskim realizowane przez inną osobę.

Kontrakt pożyczki morskiej, pomimo, iż formalnie oparty na schemacie jurydycznym kontraktu mutuum ${ }^{4}$, stanowił w rzeczywistości formę, w której strony realizowały wspólnie zyski z handlu morskie-

3 Por. w szczególności D. 45,1,122,1; D. 22,2,4,1.

${ }^{4}$ Por. G. Purpura, Tabulae Pompeianae..., s. 262-263; H. Ankum, Quelques observations sur le prêt maritime dans le droit romain préclassique et classique, [w:] Symboles, Athènes 1994, s. 105-113; w szczególności 109; V. Giuffrè, 'Faenus' 
go i dzieliły się ryzykiem związanym z nawigacją. Pożyczkodawca brał na siebie ryzyko utraty zainwestowanych środków w przypadku, kiedy statek nie dopłynął do portu przeznaczenia, pożyczkobiorca był obciążony pozostałym ryzykiem wspólnego przedsięwzięcia. W przypadku pomyślnie zrealizowanej podróży handlowej pożyczkodawca otrzymywał zwrot zainwestowanych środków wraz z wysokimi odsetkami stanowiącymi jego udział w zysku, natomiast pożyczkobiorcy przypadała pozostała część zysków. W sytuacji, w której nie spełnił się warunek si salva navis pervenerit, pożyczkodawca tracił zainwestowane środki, pożyczkobiorca mógł zaś utracić statek wraz z załoga, a nawet życie. Obie strony miały również wpływ na przebieg inwestycji, ponieważ najpierw szczegółowo ustalały trasę podróży i terminy, w których statek miał przebywać na morzu, a następnie mogły w toku realizacji przedsięwzięcia w miarę potrzeby wspólnie modyfikować te ustalenia, ponieważ pożyczkodawca był reprezentowany na statku przez swojego agenta.

Od strony procesowej roszczenie pożyczkodawcy o zwrot pożyczki zwyczajowo zabezpieczane było poprzez zastrzeżenie kary umownej (stipulatio poenae) na wypadek, gdyby dłużnik nie wywiązał się ze zobowiązania do zwrotu pożyczki, a także poprzez ustanowienie zastawu lub hipoteki na towarach przewożonych przez dłużnika na jego statkach.

Zabezpieczenie rzeczowe pożyczkodawcy mogły stanowić zarówno towary nabyte ze środków pochodzących z udzielonej przez niego pożyczki, jak i towary, które transportował pożyczkobiorca na innych statkach i które zostały zakupione ze środków pochodzących od innych inwestorów ${ }^{5}$. Praktykę ustanawiania takiego zabezpieczenia po-

e intraprese commerciali, «Seminarios Complutenses de Derecho Romano» 7/1995, s. 145; S. Schuster, op. cit., s. 186-188.

${ }^{5} \mathrm{Na}$ temat zabezpieczeń rzeczowych w kontrakcie pożyczki morskiej por. w szczególności: A. Castresana Herrero, op. cit., 113-118; G. Thür, HypothekenUrkunde eines Seedarlehens für eine Reise nach Muziris und Apographe für die Tetarte in Alexandreia (zu P. Vindob. G 40.822), «Tyche» 2/1987, s. 229-245; K. TANEV, The real securities in the agreement on the 'traiecticia pecunia', «OIR»4/1998, s.76-84. 


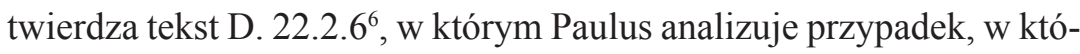
rym pożyczkodawca miał zastaw na nabytych z jego pożyczki towarach transportowanych na określonym statku, a na wypadek, gdyby ich wartość okazała się niewystarczająca, zastrzegł sobie prawo zastawu także na innych towarach transportowanych na innych statkach, na których pożyczkobiorca transportował towar nabyty za pieniądze uzyskane z kredytu od innych pożyczkodawców.

Tekst ten jest szczególnie interesujący z punktu widzenia instrumentów prawnych służących pożyczkodawcy do zminimalizowania ryzyka związanego z inwestowaniem środków w handel morski, ukazuje bowiem, iż także inne ryzyko, niż ryzyko zatonięcia statku z przyczyn działania siły wyższej, było przez niego ograniczane poprzez zabezpieczenie zastawem innego mienia dłużnika, niż towary nabyte ze środków pochodzących z udzielonej przez niego pożyczki.

D. 22,2,6 (Paul., 25 quaest.): Faenerator pecuniam usuris maritimis mutuam dando quasdam merces in nave pignori accepit, ex quibus si non potuisset totum debitum exsolvi, aliarum mercium aliis navibus impositarum propriisque faeneratoribus obligatarum si quid superfuisset, pignori accepit. quaesitum est nave propria perempta, ex qua totum solvi potuit, an id damnum ad creditorem pertineat, intra praestitutos dies amissa nave, an ad ceterarum navium superfluum admitti possit. respondi: alias quidem pignoris deminutio ad damnum debitoris, non etiam ad creditoris pertinet: sed cum traiecticia pecunia ita datur, ut non alias petitio eius creditori competat, quam si salva navis intra statua

\footnotetext{
${ }^{6}$ Por. krytyka powyższego tekstu pod kątem interpolacji: F. DE Martino, Sul 'foenus nauticum', «Rivista del Diritto della Navigazione»1.1/1935, s. 217-247, w szczególności s. 241-242 = Sul'foenus nauticum', [w:] Diritto, economia e società nel mondo romano, I: Diritto privato, Napoli 1995, s. 1-31, w szczególności s. 2324. W. Litewski, Römisches Seedarlehen, «Iura» 24/1973, s. 173 wraz z uwagami w: A. Castresana Herrero, op. cit., s. 114-115. Praktykę ustanawiania zastawu na towarach nabytych ze środków pochodzących z pożyczki potwierdza również tekst Scaevoli umieszczony przez kompilatorów w Digestach (D. 45,1,122,1), w którym jurysta analizuje kazus pożyczki morskiej udzielonej Callimachusowi.
} 
tempora pervenerit, ipsius crediti obligatio non exsistente condicione defecisse videtur, et ideo pignorum quoque persecutio perempta est etiam eorum, quae non sunt amissa. si navis intra praestitutos dies perisset, et condicionem stipulationis defecisse videri, ideoque sine cause de pignorum persecutione, quae in aliis navibus fuerunt, quaeri. quando ergo ad illorum pignorum persecutionem creditor admitti potuerit? scilicet tunc cum condicio exstiterit obligationis et alio casu pignus amissum feurit vel vilius distractum vel si navis postea perierit, quam dies praefinitus periculo exactus fuerit.

Jurysta analizuje w powyższym tekście następujące zagadnienie: jeżeli statek wraz z zastawionymi towarami, nabytymi ze środków pochodzących z pożyczki udzielonej przez tego konkretnego wierzyciela, których wartość wystarczała na zaspokojenie całości wierzytelności (ex qua totum solvi potuit), zatonął, to czy wierzyciel będzie mógł zrealizować swoje prawo zastawu w odniesieniu do towarów przewożonych na pozostałych statkach. W odpowiedzi stwierdza, iż chociaż generalną regułą jest, że ryzyko utraty przedmiotu zastawu spoczywa na dłużniku, nie na wierzycielu, to jednak w przypadku pożyczki morskiej - ponieważ wierzyciel może zażądać od dłużnika zwrotu pożyczki tylko, jeżeli w określonym w umowie czasie statek przybędzie do portu przeznaczenia - skoro statek, na którym transportowane były towary nabyte ze środków pochodzących od tego pożyczkodawcy, zatonął, wygasło prawo tego pożyczkodawcy do żądania zwrotu pożyczki i wygasło również prawo zastawu zabezpieczające tą wierzytelność ${ }^{7}$. Jako przykład sytuacji, w której wierzyciel z tytułu tak zabezpieczonej pożyczki morskiej miałby prawo zrealizować swoje prawo

7 Zdaniem F. De Martino, op. cit., s. 24, tekst ten potwierdza, iż rzymska pecunia traiecticia różniła się od greckiego kontraktu, będącego jej odpowiednikiem, ponieważ zastaw, jako zabezpieczenie wierzytelności, podporządkowany był warunkowi si salva navis pervenerit, a nie istnieniu przedmiotu zastawu. G. PURPURA, Ricerche..., s. 133, krytykuje ten pogląd, utrzymując, iż także w prawie greckim, zakładając wielość zastawów podporządkowanych jednej wierzytelności wynikającej z zawartego kontraktu pożyczki morskiej, rozwiązanie byłoby identyczne, gdyż możliwość zrealizowania 
zastawu na towarach przewożonych na pozostałych statkach, podaje kilka możliwości, z których pierwszą jest sytuacja, w której co prawda spełnił się warunek si salva navis pervenerit, ale towary nabyte ze środków pochodzących z pożyczki udzielonej przez tego wierzyciela zostały utracone w inny sposób niż poprzez wydarzenie zaistniałe na morzu kwalifikowane jako siła wyższa. Drugi przypadek to sytuacja, w której po szczęśliwym przypłynięciu statku do kresu podróży, zastawione towary zostały sprzedane po cenie niższej, niż średnia cena możliwa do uzyskania za nie na wolnym rynku, co spowodowało, że uzyskana za nie zapłata nie wystarczyłaby na zaspokojenie całości długu. Trzeci przypadek to kazus, w którym statek nie dopłynął do portu przeznaczenia intra praestitutos dies, kiedy to po upływie tego terminu periculum creditoris wygasło, a więc dłużnik był nadal zobowiązany do zwrotu pożyczki, mimo zatonięcia statku, i zgodnie z wyrażoną wcześniej przez Paulusa zasadą, iż ryzyko utraty przedmiotu zastawu obciąża dłużnika, wierzyciel miał prawo zaspokojenia się z towarów przewożonych na pozostałych statkach.

Stan faktyczny przedstawiony przez Paulusa nie jest jednoznacznie interpretowany przez autorów podejmujących temat zabezpieczeń rzeczowych w kontrakcie pożyczki morskiej. Kupiszewski twierdził, że pożyczkobiorca był właścicielem zarówno statku, który zatonął, na którym przewożone były towary pożyczkodawcy, jak i innych statków, na których przewożone były towary zabezpieczone zastawami na rzecz innych pożyczkodawców, którzy mieli pierwszeństwo w ich realizacji (pożyczkodawcy, którego statek zatonął przysługiwał zastaw tylko w odniesieniu do nadwyżki wartości tych towarów pozostałej po odliczeniu długów pozostałych faeneratores) ${ }^{8}$. Z kolei zdaniem Purpury,

zastawu lub hipoteki była w tym prawie zależna od szczęśliwego przybycia statku do portu przeznaczenia.

${ }^{8}$ Por. H. KuPISZEwski, Sul prestito marittimo nel diritto romano classico: profili sostanziali e processuali, «Index» 3/1972, s. 371. Zdaniem tego autora, Paulus wypowiada się twierdząco o możliwości realizacji prawa zastawu na towarach transportowanych na innych statkach, nawet, jeżeli statek, którym przewożone były towary zakupione ze środków pochodzących z pożyczki udzielonej przez tego pożyczkodawcę, zatonął. Pogląd ten nie jest jednak uzasadniony w świetle tekstu 
towary transportowane na pozostałych statkach, nie musiały być obciążone zastawami na rzecz innych pożyczkodawców przez tego samego dłużnika, bowiem możliwa do przyjęcia była także interpretacja, zgodnie z która, razem płynęły statki kilku pożyczkodawców, którzy udzielili pożyczek różnym osobom ${ }^{9}$. Niezbyt zrozumiała wydaje się natomiast interpretacja tego tekstu zaproponowana przez Taneva. Autor ten przedstawia omawiany stan faktyczny jako sytuację, w której pierwszy statek, na którym transportowane były towary pożyczkodawcy i który to statek następnie zatonął, był własnością pożyczkobiorcy, natomiast pozostałe statki należały do innych pożyczkodawców będących wierzycielami tego pierwszego pożyczkodawcy ${ }^{10}$, którzy również wyłożyli pieniądze na sfinansowanie tej podróży morskiej. Dalej autor ten twierdzi, że realizacja tych pozostałych zastawów mogła nastąpić tylko wtedy, jeżeli wartość towarów zastawionych na statku należącym do dłużnika po ich spieniężeniu nie wystarczyła na zapłatę długu. Zaproponowana przez Taneva interpretacja nie wydaje się być zgodna ze stanem faktycznym przedstawionym przez Paulusa, w moim przekonaniu bowiem tekst Paulusa dotyczy sytuacji, w której dłużnik pożyczał pieniądze od kilku osób na zakup towarów transportowanych drogą morską. Każda z tych osób jako zabezpieczenie uzyskiwała prawo zastawu na towarach zakupionych za jej pieniądze i transportowanych na odpowiednich statkach Nie jest też jasne dlaczego pożyczkodawca pożyczający pieniądze pożyczkobiorcy miał-

Paulusa. Por. A. Biscard, Actio pecuniae traiecticiae. Contributo alla dottrina delle clausole penali, Siena 1947 (II ed. Torino 1974), s. 181-185.

9 Dzięki takiej interpretacji można, zdaniem G. PurPury, Ricerche, cit., s. 229; s. 273-278, uzasadnić podporządkowanie zastawu na innych statkach warunkowi si salva navis pervenerit, uzależniającemu możliwość realizacji tych dodatkowych zastawów od szczęśliwego dopłynięcia do portu statku, na którym transportowane były towary zabezpieczone zastawem głównym.

${ }^{10}$ K. TANEV, op. cit., s. 79, pisze: "This merchandises laying in the debtor's ship and in the lender's - creditors' ships are pledged. It is important to point out that the other persons (nie do końca jest jasne, jakie inne osoby mu ma na myśli autor, ale z kontekstu wynika, iż chodziło mu o pozostałych pożyczkodawców) mentioned in the text are creditors to the lender. In addition they are specified as ship owners. It was agreed that the merchandises in their vessels shall secure the first debtor obligation". 
by mieć zastaw na towarach przewożonych na statkach należących do jego własnych wierzycieli. Rathbone ${ }^{11}$ uważa z kolei, iż w opisanym tekście pożyczki były udzielane kilku osobom będącym wspólnikami, bowiem w przypadku, gdyby wszystkie statki należały do tych samego dłużnika, nie byłoby motywu dla ustanawiana tych subsydiarnych zastawów na pozostałych statkach. Jego zdaniem, w takiej spółce, nawet jeżeli jeden ze wspólników utracił towary, które transportował swoim statkiem, miał on jednak udział w całości zysku wypracowanego przez spółkę, a więc pośrednio zyskach z innych szczęśliwie zakończonych przez pozostałych socii podróży, co pozwalało wierzycielowi żądać zwrotu zainwestowanych środków. Interpretacja ta nie wydaje się jednak słuszna, bowiem, w świetle tego, co stwierdza Paulus, zatonięcie statku $\mathrm{z}$ ładunkiem obciążonym pierwotnym zastawem uniemożliwiało wierzycielowi żądanie zwrotu pożyczki, a tym samym każde prawo zastawu zabezpieczające tą wierzytelność wygasało.

Nie jest do końca jasne, czyją własnością były statki, na których dłużnik transportował towary. Użyty dwukrotnie przez Paulusa zaimek proprius (aliarum mercium aliis navibus impositarum propriisque faeneratoribus obligatarum i quaesitum est nave propria perempta, ex qua totum solvi potuit, an id damnum ad creditorem pertineat), mógłby sugerować, iż statki należały do pożyczkodawców - wierzycieli. Dodatkowym argumentem za taką interpretacją może być również fakt, iż zastaw dotyczył tylko towarów transportowanych na tych statkach (a więc majątku pożyczkobiorcy ponieważ zostały te towary nabyte ze środków pochodzących z pożyczki ${ }^{12}$ ), a nie również samych

11 Por. D. Rathbone, The Financing of Maritime Commerce in the Roman Empire, I-II AD, [w:] Credito e moneta nel mondo romano. Atti degli Incontri capresi di Storia dell' economia antica (Capri 12-14 ottobre 2000), a cura di E. Lo Cascio, Bari 2003, s. 214-215.

${ }^{12}$ K. TANEV, op. cit., s. 79, twierdzi, że nie można ustalić, do kogo należały towary transportowane na innych statkach. W moim przekonaniu, skoro były to towary nabyte przez dłużnika za pożyczone pieniądze, można utrzymywać, iż były one jego własnością i jako jego majątek stanowiły zabezpieczenie wierzytelności o zwrot udzielonej na ich zakup pożyczki. 
statków $^{13}$. Przyjmując takie założenie, należy uznać, że Paulus opisywał w analizowanym tekście sytuację, gdy pożyczkobiorca otrzymywał pieniądze od kilku inwestorów, którzy jednocześnie dostarczali statek, po czym za otrzymane pieniądze nabywał towary, w celu ich sprzedaży z zyskiem. Każdy z pożyczkodawców, jako zabezpieczenie swojej wierzytelności, uzyskiwał zastaw na towarach należących do dłużnika, ale nabytych za pieniądze pochodzące z jego pożyczki i transportowanych na należącym do niego statku, a jako dodatkową gwarancję, zastaw na towarach nabytych przez dłużnika za pieniądze pochodzące z pożyczek innych pożyczkodawców, z zastrzeżeniem że ten dodatkowy zastaw mógł być zrealizowany tylko wówczas, gdy zastaw główny okazywał się niewystarczający na spłatę długu i tylko po uprzednim zaspokojeniu wierzycieli, za których pieniądze zostały nabyte towary stanowiące ten dodatkowy zastaw i którzy mieli również zastaw główny na tych towarach.

Druga możliwość interpretacji tego tekstu opiera się na założeniu, że statki, na których dłużnik transportował towary nabyte ze środków pochodzących z pożyczek udzielonych przez różnych wierzycieli, były własnością dłużnika ${ }^{14}$, a więc Paulus używa terminu proprius nie w sensie jurydycznym, ale w celu wskazania statku, na który załadowane były towary nabyte z pożyczki udzielonej przez konkretnego wierzyciela, jako statku, który w pewnym sensie był jemu właściwy, do niego ,przypisany” (poprzez fakt, iż stanowił środek transportu jego towarów), gdyż jego zatonięcie wraz towarami powodowało niemożność wystąpienia przez niego ze skargą o zwrot pożyczki. Zakładając taką interpretację, należy przyjąć iż Paulus miał na myśli sytuację, w której dłużnik, będący właścicielem kilku statków, inwestował

${ }^{13}$ Gdyby statek, na którym transportowane były towary zastawione na rzecz pierwszego pożyczkodawcy, był własnością pożyczkobiorcy, wówczas oprócz towaru przedmiotem zabezpieczenia mógłby być też ten statek. Poszukiwanie odmiennego mienia dłużnika, na którym miałby być ustanowiony dodatkowy zastaw, na wypadek, gdyby wartość tych zastawionych towarów nie wystarczyła na pokrycie długu, może sugerować, iż statek nie był własnością pożyczkobiorcy, ale wierzyciela, który powierzył mu go wraz z pieniędzmi na zakup towarów.

${ }^{14}$ Por. H. KuPISZEwsKi, op. cit., s. 371. 
w handel morski środki finansowe pochodzące od kilku pożyczkodawców i każdy z wierzycieli miał ,przypisany” do siebie statek, na który załadowane były towary nabyte ze środków pochodzących z jego pożyczki i w przypadku zatonięcia tego statku nie miał prawa do żądania od dłużnika zwrotu pożyczki. Jednocześnie, jako zabezpieczenie swojego roszczenia o zwrot zainwestowanych środków, pożyczkodawca ten miał prawo zastawu na towarach nabytych za pożyczone przez niego pieniądze i przewożonych na tym statku oraz, jako dodatkowe zabezpieczenie, prawo zastawu na towarach transportowanych na innych statkach dłużnika, przy czym to ostatnie mógł zrealizować tylko przy założeniu, że wartość towarów pochodzących z jego pożyczki nie wystarczała na zaspokojenie całej wierzytelności. Wydaje się jednak, że kwestia własności statku w omawianym przez Paulusa kazusie nie ma decydującego znaczenia dla rozstrzygnięcia zagadnienia analizowanego przez tego jurystę.

Interesująca jest hipoteza zaproponowana przez Purpurę, który sugeruje związek między stanem faktycznym opisanym przez Paulusa, a sposobem, w którym, jego zdaniem, pożyczkodawcy inwestujący swój majątek w handel morski ograniczali związane $\mathrm{z}$ taką inwestycją ryzyko, poprzez formułę wzajemnej gwarancji udzielanej sobie nawzajem przez pożyczkobiorców ${ }^{15}$. Autor ten sugeruje, iż w kazusie analizowanym przez Paulusa pozostali pożyczkodawcy udzielili pożyczek innym osobom, niż dłużnik pierwszego wierzyciela, a więc zakłada istnienie kilku pożyczek udzielonych kilku pożyczkobiorcom. Między takimi pożyczkobiorcami istniało porozumienie, na mocy któ-

15 G. Purpura, Ricerche..., s. 145-146, odwołuje się do słynnego tekstu Plutarcha, dotyczącego Katona Starszego, który inwestował majątek w przedsięwzięcia w sferze handlu morskiego. Por. Plut., Cato Maior 21.6-7. Purpura twierdzi, iż w celu ograniczenia ryzyka pożyczkodawców związanego z inwestycją w sferze handlu morskiego, innego niż periculum maris, praktyką było udzielanie sobie nawzajem przez pożyczkobiorców, pożyczających środki finansowe od różnych osób, stypulacyjnej gwarancji zapewniającej wykonanie zaciągniętych przez nich zobowiązań, w przypadku, w którym spełnił się warunek si salva navis pervenerit. Dzięki takiej formule wzajemnej gwarancji, pożyczkodawcy inwestujący środki w handel morski, zabezpieczali się na wypadek niewypłacalności dłużnika z przyczyn nie powodujących zwolnienia tegoż dłużnika z obowiązku zwrotu pożyczki morskiej. 
rego, należące do nich towary zostały zastawione na zabezpieczenie udzielonych im pożyczek na takiej zasadzie, że pierwszeństwo w realizacji prawa zastawu miał zawsze ten spośród wierzycieli, za którego pieniądze zostały nabyte te towary, ale nadwyżka pozostała po takiej realizacji mogła być rozdzielona między wierzycieli innych pożyczkobiorców, jeżeli ustanowiony przez nich zastaw był niewystarczają$\mathrm{cy}^{16}$. Należy jednak zauważyć, iż w tym każdym wypadku skuteczność takiej gwarancji była uzależniona od spełnienia się warunku si salva navis pervenerit, a więc była nieskuteczna w sytuacji, jeżeli statek z towarami nabytymi za pieniądze pochodzące z pożyczki udzielonej przez konkretnego wierzyciela, nie dotarł do portu. Jej zastosowanie ograniczałoby się do sytuacji, o których zresztą wspomina w tekście Paulus, a więc utraty towarów z innego powodu niż zdarzenie siły wyższej na morzu, sprzedaży tych towarów poniżej ich ceny rynkowej, czy nie zawinięcia statku do portu $\mathrm{w}$ terminie określonym w kontrakcie, skutkiem czego było przejście ryzyka związanego z nawigacją na dłużnika i następnie zatonięcie statku.

Idąc za tokiem rozumowania Purpury możliwe jest zaproponowanie alternatywnej interpretacji stanu faktycznego rozważanego przez Paulusa. Przyjmując, iż rozważa on kazus pożyczki udzielonej jednemu pożyczkobiorcy, można rozważyć wariant, w którym drugą stroną kontraktu było kilku faeneratores. W tym przypadku każdy z nich współfinansowałby w określonej części przedsięwzięcie i każdy z nich, jako zabezpieczenie, miałby zastaw na towarach nabytych za jego część pożyczki, a jako dodatkowe zabezpieczenie, możliwość zaspokojenia się z nadwyżki pozostałej po spieniężeniu towarów zasta-

${ }^{16}$ G. Purpura, Ricerche..., s. 180-181, zauważa również, że omawiany fragment pochodzi z księgi 25 quaestiones Paulusa, w której Lenel zamieścił też inny fragment, w którym Paulus zajmuje się problemem wielości dłużników zobowiązanych z jednego tytułu do zapłaty odsetek (D. 22,1,11) i sugeruje, że być może w tej samej księdze Paulus zajmował się również przypadkiem pożyczek morskich zabezpieczonych wzajemnymi gwarancjami stypulacyjnymi dłużników. Sam autor ostrożnie zauważa, że jego hipoteza nie może w żadnym wypadku być uznana za ,risolutiva”, ale nie jest wykluczona, biorąc pod uwagę, iż z tekstu Paulusa nie wynika, czy chodziło o zastawy ustanowione przez jednego dłużnika na rzecz różnych wierzycieli, czy przez kilku dłużników, którzy udzielali sobie nawzajem takiej gwarancji. 
wionych na rzecz innych wierzycieli. Taka interpretacja wyjaśniałaby związek między zastawami na rzecz poszczególnych wierzycieli, bowiem zastawy te stanowiłyby zabezpieczenie jednego zobowiązania, jak również logiczną byłaby zasada, że pierwszeństwo zaspokojenia się z przedmiotu zastawu miałby wierzyciel, którego część pożyczki finansowała nabycie tych towarów. Stan faktyczny analizowany przez Paulusa przedstawiałby się więc następująco: pożyczkobiorca organizujący morską wyprawę handlową pożycza pieniądze od kilku osób i każda $z$ tych osób otrzymuje jako zabezpieczenie zastaw na towarach, które mają być nabyte za jej część pożyczki i transportowane na określonym statku (nie jest wykluczone, że również statek mógł być własnością wierzyciela, który udostępniał go dłużnikowi by ten transportował na nim towary, które miały być nabyte zgodnie z umową). W sytuacji, w której, mimo spełnienia się warunku si salva navis pervenerit, dłużnik nie zwrócił pożyczki i wierzyciele przystąpili do realizacji zastawu, dodatkowym zabezpieczeniem wierzycieli, na wypadek gdyby wartość towarów nabytych za ich środki okazała się być nie wystarczająca, jest możliwość zaspokojenia się z nadwyżki, która pozostała po sprzedaży innych towarów zabezpieczających część wierzytelności innych faeneratores, aż do wyczerpania wartości wszystkich towarów ${ }^{17}$.

W moim przekonaniu niekoniecznie jednak należy zakładać, iż między pożyczkodawcami w omawianym fragmencie istniała jakaś relacja prawna, uzasadniająca objęcie zastawem, nie tylko towarów zakupionych ze środków pochodzących z pożyczki udzielonej przez pożyczkodawcę, na rzecz którego ustanawiany był taki zastaw, ale także towarów transportowanych na innych statkach, nabytych przez pożyczkobiorcę

${ }^{17} \mathrm{~W}$ praktyce greckiej, jeżeli dłużnik nie zwrócił pożyczki, ponieważ nie udało mu się uzyskać spodziewanych zysków, wierzyciel miał prawo przejęcia przedmiotu zastawu i spieniężenia go, tak, by odzyskać całość lub część swojej należności. W rozważanym przypadku można więc sobie wyobrazić, iż realizacja prawa zastawu mogła wyglądać podobnie: wierzyciele przejmowali wszystkie towary i sprzedawali każdy swoją część, a jeżeli któryś sprzedał za więcej, niż wynosiła wartość finansowanej przez niego części pożyczki, wówczas nie zwracał nadwyżki dłużnikowi, ale przekazywał ją tym wierzycielom, którzy przy realizacji prawa zastawu nie odzyskali w całości przypadającej na nich części wierzytelności. 
ze środków pochodzących od innych inwestorów. Zakładając, iż towary, które pożyczkobiorca transportował na pozostałych statkach były jego własnością, mogły one stanowić dodatkowe zabezpieczenie roszczenia pożyczkodawcy o zwrot pożyczki morskiej wraz z odsetkami, ustanowione na wypadek, gdyby wartość towarów objętych głównym zastawem nie wystarczała na zaspokojenie w całości roszczenia tego pożyczkodawcy. W tej sytuacji było naturalnym, iż inni pożyczkodawcy, którzy wyłożyli środki na zakup tych towarów, mieli pierwszeństwo w realizacji prawa zastawu przed tym pożyczkodawca, bowiem, zgodnie z zasadą wyrażoną w D. 20,4,7pr.-1, wierzyciel, który udzielał pożyczki na zakup przedmiotu zastawu, a więc za którego środki została nabyta rzecz, będąca na podstawie wcześniejszej umowy przedmiotem zabezpieczenia, miał pierwszeństwo w zaspokojeniu się z tego przedmiotu zastawu przed innymi wierzycielami ${ }^{18}$. Po jego zaspokojeniu, pozostała nadwyżka mogła stanowić zabezpieczenie innych wierzytelności, które miały w stosunku do tego pożyczkobiorcy osoby trzecie.

Niezależnie jednak od kwestii istnienia relacji prawnej łączącej pożyczkodawców w kazusie przedstawionym przez Paulusa, moim zdaniem najbardziej prawdopodobna jest interpretacja tego tekstu za-

18 D. 20,4,7 pr.-1 (Ulp. 3 disp.): Idemque est, si ex nummis pupillifuerit res comprata. Quare si duorum pupillorum nummis fuerit res comprata, ambo in pignus concurrent pro his portionibus, quae in pretium rei fuerunt expensae. Quod si res non in totum ex nummis cuiusdam comprata est, erit concursus utriusque creditoris, id est et antiquioris et eius cuius nummis comprata est. 1. Si tibi quae habiturus sum obligaverim et Titio specialiter fundum, si in dominium meum pervenerit, mox dominium eius adquisiero, putat Marcellus concurrere utrumque creditorem et in pignore: non enim multum facit, quod de suo nummos debitor dederit, quippe cum res ex nummis pigneratis empta non sit pignerata ob hoc solum, quod pecunia pignerata erat. Tekst ten dotyczy co prawda nabycia przedmiotu zastawu za pieniądze pochodzące z majątku pupila, co może sugerować, iż powodem uprzywilejowania wierzytelności jest szczególna ochrona za strony prawa podopiecznego, ale podobne rozstrzygnięcie potwierdzają konstytucje cesarskie, także w przypadku udzielenia pożyczki przez wierzyciela nie będącego pupilem. Por. C. 8,17,7; C. 8,13,7. Na temat uprzywilejowania wierzytelności z pożyczki udzielonej na zakup przedmiotu zabezpieczenia i fragmentu D. 20,4,7 pr.-1 por. I. SzPringer, Pierwszeństwo zastawów w prawie rzymskim, Lublin 2006, s. 116-119. 
kładająca jedną albo kilka pożyczek udzielonych temu samemu dłużnikowi przez kilku pożyczkodawców, tekst ten bowiem wspomina o wielości wierzycieli, ale nie dłużników. Taka interpretacja również pozwala uzasadnić związek między zastawami ustanawianymi na rzecz różnych pożyczkodawców. Pożyczkobiorca, jako osoba organizująca morską wyprawę handlową, angażował środki pochodzące od kilku osób, w zamian za udział w zyskach z takiego przedsięwzięcia (nadwyżkę, która pozostała $\mathrm{z}$ pieniędzy uzyskanych ze sprzedaży towarów po spłacie pożyczki wraz z odsetkami). W tej inwestycji każdy finansujący ponosił ryzyko zatonięcia statku, na którym przewożone były towary nabyte $\mathrm{z}$ jego środków, ale mógł spodziewać się zysku w formie odsetek wyższych niż maksymalna stopa odsetek przewidziana dla zwykłego kontraktu pożyczki.

Omawiany tekst ma w moim przekonaniu szczególne znaczenie dla analizy form organizacyjnych, w których realizowane były przedsięwzięcia związane z handlem morskim. Pomimo, iż na jego podstawie nie można $\mathrm{z}$ całą pewnością stwierdzić, jaki był dokładnie stan faktyczny opisywany przez Paulusa, jednak tekst ten sugeruje, iż schemat takich inwestycji nie ograniczał się tylko do prostego modelu, w którym występował jeden inwestor i jeden pożyczkobiorca, ale w praktyce struktura takich inwestycji mogła być dużo bardziej skomplikowana. Ponadto tekst ten ukazuje, iż pożyczkodawca w kontrakcie pożyczki morskiej starał się nie tylko zminimalizować ciążące na nim periculum creditoris (przez ustalenie trasy i terminów odbycia przez pożyczkobiorcę podróży morskiej, bieżącą kontrolę realizacji przedsięwzięcia za pośrednictwem agenta, podróżującego razem z pożyczkobiorcę), ale także zabezpieczał się przed pozostałym ryzykiem związanym z zainwestowaniem środków w handel morski, związanym, np. z zatonięciem statku po upływie terminu określonego w umowie, sprzedażą zakupionych ze środków pochodzących z pożyczki towarów poniżej ich ceny rynkowej, czy utratą tych towarów, już po szczęśliwym powrocie statku do portu przeznaczenia. 
Pledge as a Security in Maritime Loan in D. 22,2,6

\section{Summary}

In the maritime loan, as the best known form of investing money in maritime trade, the credit was used to buy merchandise carried on a ship. If a ship perished with the merchandise, the borrower was not obliged to repay a loan. As in this type of loan the creditor undertook the risk of the perishing of the ship (periculum maris), as a reward he could stipulate the interest exceeding the legal rate in case of a successful journey. In order to reduce his risk, the lender decided about the details of the journey: the route, the dates of sea voyage and merchandise acquired and he also often supervised the proper performance of the borrower's obligations through his agent travelling with the latter.

Apart from the risk of the perishing of the ship, the lender undertook also the risk of the debtor's insolvency being a result of different events than the perishing of the ship (as for example the perishing of merchandise after the condition si salva navis was fulfilled). That other risk could be reduced to some extend through a pledge over the merchandise purchased from the loan and carried by the borrower on the ship. The text of D. 22,2,6 refers to a special case of such a pledge.

In the case analyzed by Paulus the creditor as a security of his loan had a pledge non only over the merchandise purchased from his loan, but also, in case in which his whole debt could not be discharged from these goods, over any surplus of the other goods loaded on the other ships and under pledge to their respective moneylenders. This text was widely discussed among romanists, who did not agree about the legal basis of making such subsidiary pledges. It was suggested that among faeneratores some kind of partnership existed or that the debtors were more than one and they were bound reciprocally by a mutual surety. In my opinion it cannot be excluded that those lenders made a part of one contract of maritime loan. Each of them undertook the risk of the perishing of the ship on which there were loaded goods purchased from his part of the loan, and as a security, each of them had a pledge over the goods carried on his ship, plus, subsidiarily, over the other goods purchased from the same loan but 
financed by other lenders. Anyway, it is worth noting that it's not necessary that the moneylenders in the case discussed by Paulus made a part of the same contract of the loan or were partners. Taking into consideration the rule regarding the priority of liens expressed in D. 20,4,7 pr.-1, according to which the obligation of the creditor from the credit used to acquired the goods pledged had precedence over any other obligation secured with the pledge over the same goods, it is possible to maintain that there was not any legal relation neither among lenders nor borrowers. The first lender to secure his obligation took a pledge over the goods purchased from his loan, as commonly practiced. As he wanted to protect himself better against the debtor's insolvency, he took also a pledge over the remaining property of the debtor that is merchandise carried by him in other ships. As this cargo was purchased from the loans granted by other lenders, those lenders had priority before the pledge of the first lender.

In spite of many controversies, the text discussed provides us with precious information regarding the financing of the maritime trade in ancient Rome, as it shows that not only periculum maris, but also other risk related to the investment in maritime commerce, was reduced by lenders. It also suggests that the legal structure of such an investment could be more complex than a simple scheme consisted of one lender and one borrower. 